\title{
Research on Edible Oil Quality and Safety System
}

\author{
Lei Maochong \\ Wuhan Technology and Business University \\ A Sub-item of Modern Logistics and Business Collaborative Innovation Center in Hubei Province \\ 365843234@qq.com
}

\begin{abstract}
Edible oil quality and safety is related not only to human health but also to the economic development of the country and the social stability. For this reason, research on edible oil quality and safety system is very important. This paper, by applying logical reasoning and empirical analysis, analyzes situations from the current edible oil market to the edible oil quality in China, and gradually comes to the measures and methods of building Chinese edible oil quality and safety system. This article through the analysis from the current situation of market to the quality problem of the edible oil in our country, gradually comes to construct measures and methods of edible oil quality and safety system, although this article has made a preliminary plan in the establishment of edible oil quality and safety system, but there is still inadequate in many ways, which still needs further exploration and development. The research on China's edible oil quality and safety system is still a nature of an exploration.
\end{abstract}

Keywords- Edible oil; Quality and safety; Risks;

\section{Evaluation; Arowana}

\section{THE INTRODUCTION}

Edible oil, as the energy source of human body nutrition, is a very important part of human diet and an essential raw material in food processing industry. Therefore, the edible oil plays a very important role in our daily life. The quality and safety of edible oil can easily be affected by many factors including methods of oil production and processing, distribution and catering services, food additives and food production as well as packaging materials. People are paying more and more attention to it now.

(1) Edible oil quality and safety system must be established to ensure people's health and to comprehensively promote the economic development. But in recent years, the quality and safety of agricultural products have been getting worse.

(2) In order to increase farmers' income, it is necessary to adjust the agricultural structure while keeping strengthening the quality and safety management of edible oil.

(3) Strengthening the quality and safety management of edible oil can help to protect the environment and improve the ecological environment; meanwhile, it can also promote economic development and keep sustainable development.

\section{The CuRRent Situation OF Edible Oil In ChinA}

Oil fat is an important nutrient for human beings, and edible oil is essential in our daily life. In this respect, how much edible oil people can consume has become an important indicator of living standards in a region and holds a significant place in the national food security.

\section{A. The production of raw materials for edible oil in \\ China}

With the reform and opening up, China has been seeing its economy continue to develop and great changes take place in edible oil production. To make people's needs match with their living standards, China gives higher priority to raw materials' production for edible oil and has seen a continual increase in the output of rapeseed, soybean, peanut, cotton seed, sunflower seed, sesame and others. Specific data are shown in Table 1:

TABLE I THE MAIN RAW MATERIALS' PRODUCTION FOR EDIBLE OIL

\begin{tabular}{|c|c|c|c|c|c|c|c|}
\hline \multicolumn{8}{|c|}{ The main raw materials' production for edible oil in China in 2000-2009 (Unit/10,000 tons) } \\
\hline Year & Peanut & Soybean & Rapeseed & $\begin{array}{c}\text { Sunflower } \\
\text { seed }\end{array}$ & Cotton seed & Others & Total \\
\hline 2000 & 1443.4 & 1540.9 & 1138.7 & 195 & 750.5 & 197.7 & 5266.2 \\
\hline 2001 & 1442.0 & 1540.6 & 1133 & 148 & 904.4 & 187.8 & 5355.8 \\
\hline 2002 & 1494.5 & 1650 & 1052.5 & 200 & 836.4 & 206 & 5439.4 \\
\hline 2003 & 1506 & 1691 & 1240 & 198.5 & 848 & 211 & 5694.5 \\
\hline 2004 & 1430 & 1720 & 1303 & 197 & 1075 & 210 & 5937 \\
\hline 2005 & 1470 & 1880 & 1120 & 170 & 960 & 199.5 & 5799.5 \\
\hline 2006 & 1380 & 1380 & 1220 & 168 & 1211 & 191.1 & 5720.1 \\
\hline 2007 & 1400 & 1400 & 1200 & 180 & 1260 & 177.5 & 5617.5 \\
\hline 2008 & 1500 & 1550 & 1180 & 220 & 1350 & 250 & 6050 \\
\hline 2009 & 1471 & 1498.1 & 1365.5 & 195 & 1274.1 & 210.9 & 6015.1 \\
\hline
\end{tabular}




\section{B. The imports and exports of raw materials for edible oil in China}

Although the production of oil fat and raw materials for edible oil develops rapidly in China, our needs for edible oil still cannot be met as the economy develops and people's living standards are improved in a quick way. In order to meet its people's needs for edible oil, China has to raise the edible oil supply.

TABLE II THE IMPORTS AND EXPORTS OF RAW MATERIALS FOR EDIBLE OIL IN CHINA

\begin{tabular}{|c|c|c|c|c|c|c|c|}
\hline \multicolumn{8}{|c|}{ The imports and exports of raw materials for edible oil in China in 2000-2010 (Unit/10,000 tons) } \\
\hline Year & $\begin{array}{c}\text { Annual } \\
\text { imports } \\
\text { converted into } \\
\text { oil } \\
\end{array}$ & Soybean oil & Rapeseed oil & Soybean & Rapeseed & $\begin{array}{l}\text { Annual exports } \\
\text { converted into } \\
\text { oil }\end{array}$ & $\begin{array}{c}\text { Annual net } \\
\text { imports } \\
\text { converted } \\
\text { into oil } \\
\end{array}$ \\
\hline 2000 & 496.9 & 30.5 & 7.8 & 1041.3 & 297.2 & 35.5 & 461.4 \\
\hline 2001 & 514.4 & 7 & 7.3 & 1393.9 & 172.4 & 39.9 & 474.4 \\
\hline 2002 & 570.4 & 87 & 7.8 & 1131.5 & 61.8 & 38.1 & 531.3 \\
\hline 2003 & 958.3 & 188.5 & 15.2 & 2074 & 16.7 & 35.5 & 922.8 \\
\hline 2004 & 1055 & 252 & 35.3 & 2023 & 47 & 30 & 1025 \\
\hline 2005 & 1109.5 & 169.4 & 17.8 & 2659 & 29.6 & 27.6 & 1082 \\
\hline 2006 & 1281 & 154 & 4.4 & 2827 & 74 & 53 & 1228 \\
\hline 2007 & 1510 & 282 & 37.5 & 3080 & 83 & 35.6 & 1476 \\
\hline 2008 & 1614 & 250 & 27 & 3744 & 130 & 39 & 1580 \\
\hline 2009 & 2056.8 & 239.1 & 132.7 & 4255.2 & 328.6 & 20.5 & 2037 \\
\hline 2010 & 2112.7 & 134 & 98.5 & 5479.7 & 160 & 23.8 & 2090 \\
\hline
\end{tabular}

\section{Per capita consumption of edible oil in China}

As the economy develops, the output value of raw materials for edible oil in China has increased accordingly, so has the output value of the imports of raw materials. Hence, China's per capita possession of edible oil is growing. According to statistics, China's per capita annual consumption of edible oil has risen from $8.4 \mathrm{~kg}$ in 1998 up to $21 \mathrm{~kg}$ in 2008 . This level has reached and even exceeded the world's average. Specific data are shown in Table 3:

TABLE III CHINA’S EDIBLE OIL CONSUMPTION

\begin{tabular}{|c|c|c|}
\hline \multicolumn{2}{|c|}{ China's edible oil consumption in 1998-2008 } \\
\hline Year & Amount of edible oil consumption /10,000 tons & Per capita consumption /Kg \\
\hline 1998 & 1090.7 & 8.4 \\
\hline 2000 & 1247.8 & 9.7 \\
\hline 2001 & 1331 & 10.3 \\
\hline 2002 & 1412 & 11 \\
\hline 2003 & 1501 & 11.6 \\
\hline 2004 & 1750 & 13.5 \\
\hline 2005 & 1880 & 14.5 \\
\hline 2006 & 2272 & 17.6 \\
\hline 2007 & 2510 & 19.5 \\
\hline 2008 & 2685.1 & 20.7 \\
\hline
\end{tabular}

From the above data we may find that the imports of raw materials for edible oil keep increasing every year. To offer consumers high-quality edible oil requires that the oil fat and raw materials, which is a necessity for producing edible oil, must be safe in quality. China's edible oil quality and safety system must be improved so as to comply with the edible oil quality and safety standards. The following diagram is for reference: 


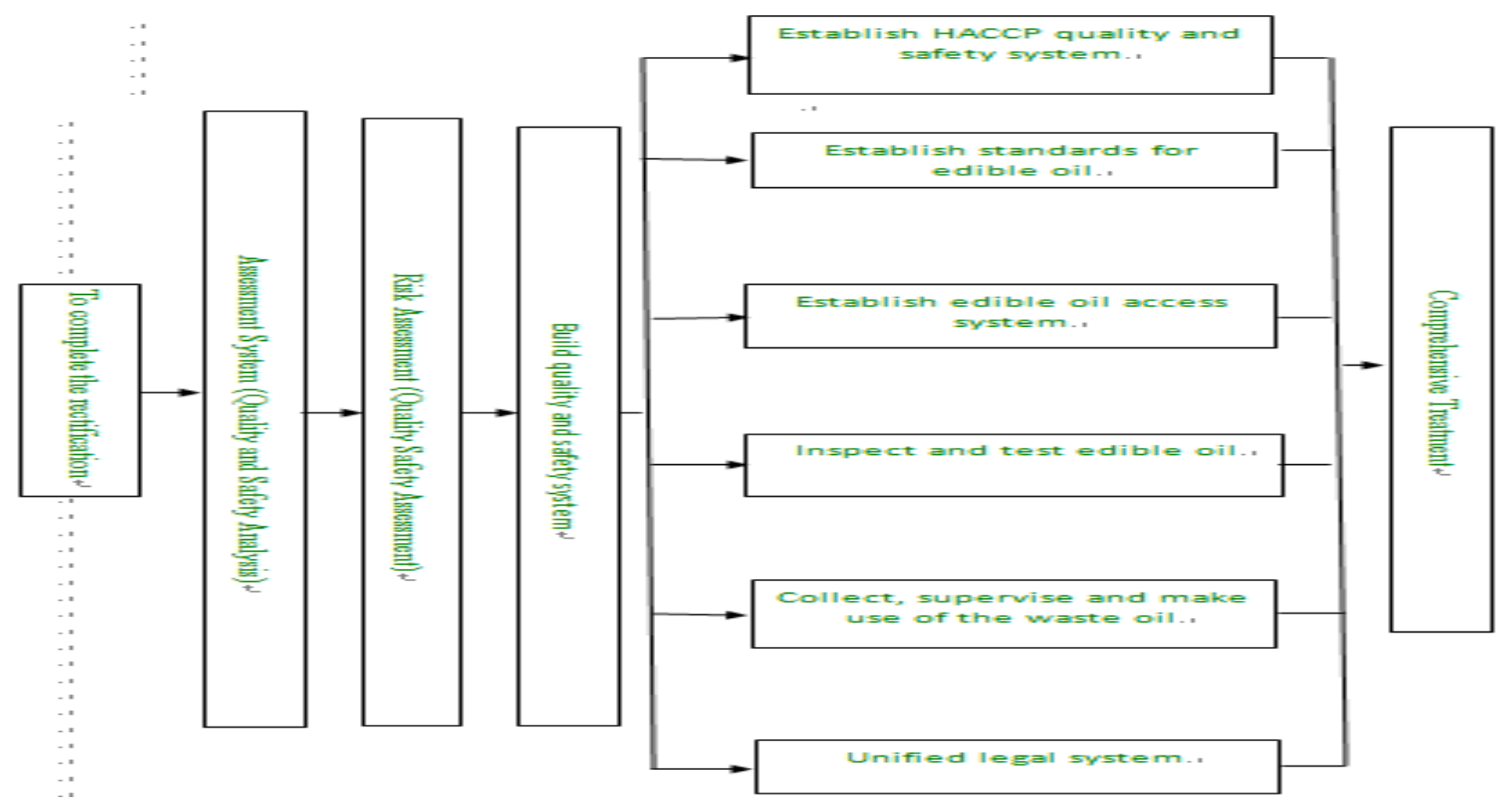

Figure 2-1 Edible oil quality and safety risk assessment procedures

\section{ANALYSIS OF EDIBLE OIL QUALITY AND SAFETY ISSUES}

Although China's edible oil processing has reached a high degree of modernization, the quality and safety of edible oil is not satisfying. Problems about edible oil quality and safety exist in many aspects. Starting from planting edible raw materials, through harvesting and storage to the final production, processing and marketing, the whole process is involved with the quality and safety of edible oil.

\section{A. Contamination of raw materials}

In the food industry, raw materials contaminated would often result in security events, such as Japan's Snow Brand Milk pollution incident in 2000, Kentucky Sudan incident in 2005, Merlin canned beef luncheon event in 2007 and so on.

\section{B. Problems in the production and processing of edible oil}

\section{1) Manufacturing enterprises lack of} standardization in operation

Failure to operate by the requirements during the production process can produce substandard quality oil. For example: excessive aflatoxin or benzpyrene not only leads to the substandard quality oil, but also threatens human health.

2) Problems on new technologies and raw materials

Having much edible oil with excessive solvent residues can damage the central nervous system, causing lesions, ranging from body function disorders to paralysis, non-neurological reflex, or shock.

\section{3) Adding industrial oil}

Industrial oils, many are very similar to edible oils, such as tung oil, due to its cheap price, some unscrupulous traders in order to reap huge profits, they add industrial oils to edible oils for sales. Consumers are difficult to distinguish them from the appearance and odor. This kind of phenomenon is very much in bulk oil sales places.

4) Adding illegal additives

In order to improve the oxidation resistance of edible oil, small amounts of oxidants can be added, such as: BHT, BHA, polyphenols, and so on. In order to improve the nutritional value of the edible oil, some vitamin VA may be added. Such additives are allowed by international and the national standards. But in order to reap huge profits, some unscrupulous traders add non-edible flavor additives in some low-quality oil, in order to act as high-quality edible oil, disrupting the market, harming consumers' health.

\section{Edible oil issues in the sales process}

Sales market of edible oil in bulk in rural areas is large, but edible oil in bulk is easily adulterated, adulteration phenomenon is present in manufacturers, wholesalers and retailers. If consumers buy edible oil with the quality issues, it is difficult define responsibilities when the relevant departments are calling for accountability.

\section{CONSTRUCTION OF EDIBLE OIL QUALITY AND}

\section{SAFETY SYSTEM}

Construction of edible oil quality and safety system is a systematic project, which requires solidarity and cooperation and ongoing efforts of the people. To establish and improve standards of cooking oil, there must be a sound, thorough edible oil quality and safety system. We should constantly strive to solve all the problems in the edible oil quality and safety system construction process, and to highlight the subject between the various systems, and coordinate the relationship between the various systems. As the following diagram, edible oil quality and safety control system: 


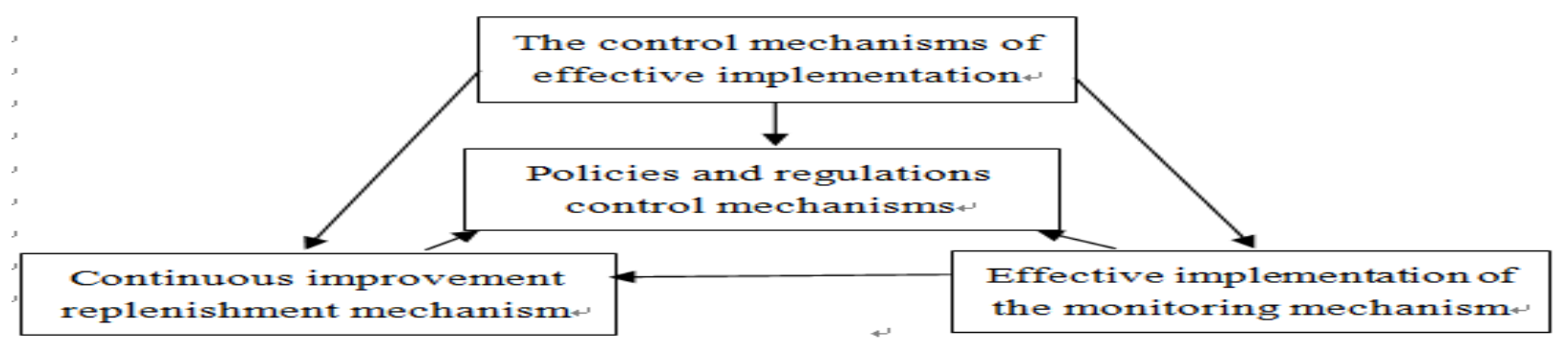

Figure 4-1 Quality and safety control system

\section{A. Establishing quality and safety system HACCP}

HACCP is a preventive safety control system of edible oil. The establishment foundation of the system is that the enterprise has good hygiene practices and standard operating procedures. Perform work-related content according to the edible oil quality and safety management system. From every aspect of the cultivation of raw materials, procurement, production, storage, transportation, quality control can be carried out, strictly controlling quality security of edible oil, to eliminate the edible oil quality problems from the source of edible oil, thereby producing a safe, healthy edible oil, for example, soybean oil production and processing of HACCP are in Table 4.

\begin{tabular}{|c|c|c|c|c|c|c|c|c|c|}
\hline \multirow{2}{*}{ CCP Point. } & \multirow{2}{*}{$\begin{array}{l}\text { Significant } \\
\text { hazard.1. }\end{array}$} & \multirow{2}{*}{$\begin{array}{l}\text { The ley } \\
\text { restrictions.y }\end{array}$} & \multicolumn{4}{|l|}{ Monitoring.r } & \multirow{2}{*}{ Correction. } & \multirow{2}{*}{ Records I. } & \multirow{2}{*}{ Verification. } \\
\hline & & & Targets. & Methods.I & Frequency. & Personnel. & & & \\
\hline \multirow[t]{2}{*}{$\begin{array}{l}\text { Raw } \\
\text { material } \\
\text { quality.s }\end{array}$} & $\begin{array}{l}\text { Mildew, } \\
\text { pesticide } \\
\text { residues, } \\
\text { breakage.. }\end{array}$ & $\begin{array}{l}\text { The value of } \\
\text { the } \\
\text { production } \\
\text { process } \\
\text { safety } \\
\text { requirements. }\end{array}$ & $\begin{array}{l}\text { Mildews, } \\
\text { pesticide } \\
\text { residues, } \\
\text { breaksge. }\end{array}$ & $\begin{array}{l}\text { Visual } \\
\text { inspection, } \\
\text { microbiological } \\
\text { testing. }\end{array}$ & $\begin{array}{l}\text { Each } \\
\text { batch. }\end{array}$ & Inspectors.? & $\begin{array}{l}\text { Rejection of } \\
\text { unqualified } \\
\text { raw } \\
\text { materials.v }\end{array}$ & $\begin{array}{l}\text { Raw } \\
\text { material } \\
\text { inspection } \\
\text { recorda. }\end{array}$ & $\begin{array}{l}\text { Daily audit } \\
\text { records.. }\end{array}$ \\
\hline & $\begin{array}{l}\text { Genetically } \\
\text { modified } \\
\text { soybesms. }\end{array}$ & $\begin{array}{l}\text { Verification } \\
\text { of safety } \\
\text { conformity.. }\end{array}$ & $\begin{array}{l}\text { Safety } \\
\text { certification.: }\end{array}$ & Mark.. & $\begin{array}{l}\text { Each } \\
\text { batch. }\end{array}$ & Inspector.2 & $\begin{array}{l}\text { Mark, and } \\
\text { separate } \\
\text { from others }\end{array}$ & $\because$ & $\begin{array}{l}\text { Each batch } \\
\text { verification. }\end{array}$ \\
\hline $\begin{array}{l}\text { Adding } \\
\text { antioxidants.. }\end{array}$ & $\begin{array}{l}\text { Use of } \\
\text { antioxidants.. }\end{array}$ & $\begin{array}{l}\text { Target market } \\
\text { stamdards and } \\
\text { requirements. }\end{array}$ & $\begin{array}{l}\text { The usage } \\
\text { and } \\
\text { effectiveness } \\
\text { of the } \\
\text { anti-oxidant. }\end{array}$ & $\begin{array}{l}\text { Hand sample } \\
\text { assay.. }\end{array}$ & $\begin{array}{l}\text { Each } \\
\text { batch.r }\end{array}$ & $\begin{array}{l}\text { Quality } \\
\text { controller } \\
\text { and } \\
\text { operator. }\end{array}$ & $\begin{array}{l}\text { Banned } \\
\text { packaging if } \\
\text { additive are } \\
\text { excessive }\end{array}$ & $\begin{array}{l}\text { Additives } \\
\text { record. }\end{array}$ & $\begin{array}{l}\text { Daily andit } \\
\text { records.. }\end{array}$ \\
\hline \multirow[t]{2}{*}{ Packing. } & $\begin{array}{l}\text { Microbial } \\
\text { growth, the } \\
\text { impurities } \\
\text { in the } \\
\text { packaging } \\
\text { container. }\end{array}$ & $\begin{array}{l}\text { Verification } \\
\text { of safety } \\
\text { conformity. }\end{array}$ & $\begin{array}{l}\text { Safety } \\
\text { certificate, } \\
\text { sealing } \\
\text { condition, } \\
\text { the container } \\
\text { sterilization } \\
\text { condition.. }\end{array}$ & $\begin{array}{l}\text { Examine and } \\
\text { verify. }\end{array}$ & $\begin{array}{l}\text { Each } \\
\text { batch.. }\end{array}$ & Inspector.7 & $\begin{array}{l}\text { Retum, } \\
\text { timely } \\
\text { adjustment. }\end{array}$ & $\begin{array}{l}\text { L aboratory } \\
\text { indicators, } \\
\text { message } \\
\text { recording. }\end{array}$ & $\begin{array}{l}\text { Daily audit } \\
\text { records. }\end{array}$ \\
\hline & $\begin{array}{l}\text { Packing } \\
\text { plant, the } \\
\text { health of } \\
\text { operators . }\end{array}$ & $\begin{array}{l}\text { Requirements } \\
\text { of safety } \\
\text { conformity. }\end{array}$ & $\begin{array}{l}\text { Packing } \\
\text { plant, the } \\
\text { operator } \\
\text { sanitation } \\
\text { and } \\
\text { disinfection.. }\end{array}$ & Inspection.. & Every day. & Inspector." & $\begin{array}{l}\text { Periodic } \\
\text { inspection } \\
\text { and } \\
\text { disinfection, } \\
\text { non-staff } \\
\text { are allowed } \\
\text { to enter. }\end{array}$ & $\begin{array}{l}\text { Sample } \\
\text { level } \\
\text { operator } \\
\text { mamagement } \\
\text { record. }\end{array}$ & $\begin{array}{l}\text { Daily audit } \\
\text { records.. }\end{array}$ \\
\hline
\end{tabular}

TABLE IV SOYBEAN OIL PRODUCTION AND PROCESSING HACCP

\section{B. Establish standards for edible oil}

Establish the national standards certification of edible oil, carry out unified certification bodies of edible oil. Thereby promote edible oil quality management system and connect it with international standards. This will help Chinese edible oil internationalize standard system and quality management system, to ensure supervision and administration of standardization, supervision and scientization.

\section{Establish the edible access system}

To implement the market access system on the edible oil market, the following aspects should be done: First, certify the edible oil to meet the requirements of quality and safety standards and permit it entering the market; Second, establish monitoring and management system; Third, label the edible oil, increase the consumer's right to know the edible oil; Fourth, take laws and regulations as the basis, under the supervision of the community, establish the combined credit system between the legal institution and moral.

\section{Cooking oil inspection and detection}

\section{1) Inspection of oil producers by functional departments}

Inspect the raw material quality control; inspect the production process quality control; inspect environment and sanitation conditions; inspect product quality control;

Increase the number of times for on-site inspection of related departments, take a random sampling method, change the original inspection of manufacturing enterprises, evaluate enterprises' quality and safety 
levels, when identifying problems, companies should be require for rectification, and be punished according to relevant laws and regulations.

\section{E. Collection, regulation and usage of the waste oil}

Relevant government departments should be united for supervision of the generation of waste cooking oil, processing, marketing and other intermediate links, to ensure that it will not flow into the edible oil market, and establish related sites for waste oils, disclose information on waste oil, exposure blackspots of illegal cooking oil.

\section{F. Unified laws and regulations system}

Establish coordinating and unifying laws and regulations system, the system must include test and monitoring in all links from raw materials to the sale, to determine the responsibility for the safety of edible oil, the transparency of edible oil security should be clear, the traceability of edible oil should be strong. Only in this way the legal system can be continuously improved.

\section{GOLD AROWANA EDIBLE OIL QUALITY AND SAFETY SYSTEM}

Gold Arowana is produced by Jiali grain and oil production, and is among the top ten brands of edible oil. In 2008, the sales of Gold Arowana has reached 2 million tons, accounting for 40 percent of the edible oil market. $7.5 \%$ of the companies in our country have created a $70 \%$ edible oil sales revenue, $42.2 \%$ of the market belongs to Gold Arowana, Fook Lam Moon and Lu Hua, three brands.

\section{A. Uniform standards}

The product quality of Jiali Oil company is ahead of the quality of similar products, belongs to the world's advanced level. In September 2010, the company passed the ISO9001: 2008 quality management system certification. It has a dual system and strict product standards to ensure product quality, there's no accident due to poor quality from going into production in 1994 to the present, in the supervision and inspection by at all levels of quality and food safety supervision departments, all the quality of products reaches the standard. Produced food is in line with national laws, regulations and contractual requirements, and is in line with quality safety regulations of national standards, quality industry standards and local standards.

\section{B. The additive standard}

Add non-food substances without breaking the law, without abuse of food additives. Use food additives according to national regulation, strictly put food additives used on records, and to express additive service condition in the product label and logo in accordance with national standards.

\section{HACCP system}

In 2005, the company passed the HACCP food safety management system certification. It is strictly in accordance with national laws, regulations and relevant standards for production to ensure to meet the environmental conditions and sanitation for production conditions of food quality and safety.

\section{Services}

Jiali grain and oil company has a complete marketing network, so the pre-sales, mid-sales and after-sales service can be done well, it can solve the problems for consumers. Through understanding of the views and the needs of consumers by business personnel, they are able to introduce appropriate products for consumers to satisfy them and keep abreast of the views and needs of consumers. Enterprises customer service hotline, consumers can call toll-free for counseling, customer service will help you out, if there are problems which are necessary for staff s presence to solve the problem, Jiali grain and oil Company will be the first time to send marketing services staff to contact you, to ensure that they can be in the shortest possible time on-site for you.

\section{RESEARCH DEFICIENCY AND PROSPECT}

This article through the analysis from the current situation of market to the quality problem of the edible oil in our country, gradually comes to construct measures and methods of edible oil quality and safety system, although this article has made a preliminary plan in the establishment of edible oil quality and safety system, but there is still inadequate in many ways, which still needs further exploration and development. The research on China's edible oil quality and safety system is still a nature of an exploration. In the establishment of China's edible oil quality and safety system there are some limitations, which needs to improve and strengthen continually in the future.

\section{REFERENCES}

[1] Wang Ruiyuan, Oil production industry of China in 2013 [J] Chinese oil, 2013,29 (8): 5-10.

[2] Zhang Mingyu, Modern logistics development and research of Chinese agricultural products - Strategy $\bullet$ mode $\bullet$ mechanism $\bullet$ Positive; Science Press; May 1st,2010

[3] Wang Ruiyuan, Development of China's oil industry in the new century and current several remarkable issues $[\mathrm{J}]$ Chinese oil, 2010,26 (6): 4-10.

[4] Handbook of agricultural products quality safety testing - fruits and vegetables and products rolls; China Standards Press; Nov 1 st, 2008

[5] Zi Meiqing, Current situation of Chinese oil production industry and thought of the development strategy of the new era $[\mathrm{J}]$ Chinese oil, 2013,28 (11): 4-12.

[6] Li Shuguo China's food safety problems and countermeasures [J] Chinese Food and Nutrition, 2012 (6): 6-12.

[7] Qiao Juan, Wang Huimin; Subject behavior of pork circulation and supervision system study based on quality safety; China Agriculture Press; Aug. 1st, 2013

[8] Huang Yuyang, Xiao Zhigang, Several food safety issues of edible vegetable oil [J] Soybean Science, 2012,127 (8): 684-690

[9] Chen Fengxiang, Determination of trans fatty acids in five kinds of edible oil in Shanghai markets $[\mathrm{J}]$ Grain and Oil Food Science and Technology, 2009,17 (1): 38-50.

[10] Wang Guangjun, Quality health and safety environment management system standards and methods; Petroleum Industry Press; Sep. 1st,2012

[11] Yang Limin, Edible oil quality and safety issues and thoughts [J] Western Development • In mid-2012 (2): 3-8.

[12] Wang Ruiyuan, Current situation of market and development trend of domestic and international oil market [J] Chinese oil, 2011,36 (6): 5-20. 